\title{
Naujai perskaitytas 1940 metų spalio 22-osios Staffordo Crippso memorandumas
}

\author{
Magdalena Hułas \\ Lenkijos mokslų akademijos Tadeuszo Manteufflo istorijos institutas \\ Tadeusz Manteufflo Institute of History at the Polish Academy of Sciences \\ mhulas@ihpan.edu.pl \\ ORCID https://orcid.org/0000-0003-0638-866X
}

\begin{abstract}
Santrauka. Šis straipsnis yra gerokai pataisyta ir išplèsta ankstesnio autorès straipsnio, 1993 m. paskelbto mokslo žurnale Dzieje Najnowsze, versija. Straipsnyje aptariamas britų pasiūlymas Sovietų vyriausybei suderinti dvišalius santykius tuo laikotarpiu, kai Sovietų Sajunga buvo susitarusi su Trečiuoju reichu (pasidalinti įtakos zonomis Vidurio ir Rytų Europoje). Šiam susitarimui susilpninti Didžiosios Britanijos vyriausybė siūlè SSRS naudingų galimybių, ypač susijusių su pokariniais sprendimais Rytų ir Vidurio Europos valstybėse. Daug dėmesio naujame susitarime skiriama Lenkijai, taip pat Estijai, Latvijai ir Lietuvai, galiausiai - Rumunijai. Pasiūlymų autorius buvo Didžiosios Britanijos ambasadorius Maskvoje seras Staffordas Crippsas. Pasiūlymams Londone buvo pritarusi karo metais veikusi vyriausybė, o britų ambasadorius (užsienio reikalų ministro ịpareigotas) turẻjo juos pateikti Sovietų vyriausybei. Straipsnyje analizuojama dokumento rengimo ir aptarimo raida, lenkų vyriausybės emigracijoje reakcija ị britų veiksmus ieškant susitarimo su Maskva. Memorandumas, $1940 \mathrm{~m}$. spalio $22 \mathrm{~d}$. S. Crippso ịteiktas SSRS užsienio reikalų liaudies komisaro pavaduotojui Andrejui J. Vyšinskiui, buvo svarbus Didžiosios Britanijos ir Sovietų Sąungos dvišalių santykių îvykis, todèl tyrinejjant ir atskleidžiant $1942 \mathrm{~m}$. gegužès $26 \mathrm{~d}$. britų ir sovietų sutarties genezę i jị turi būti kreipiama kur kas daugiau demesio. I jị turi būti atsižvelgiama ir nagrinèjant Vidurio ir Rytų Europos valstybių ir tautų likimą po Antrojo pasaulinio karo. (Straipsnis parengtas mokslo žurnalo Aktualu rytoj / Relevant Tomorrow redakcinès kolegijos prašymu. Straipsnị iš lenkų kalbos verte Andrius Vaišnys.)
\end{abstract}

Reikšminiai žodžiai: Crippso memorandumas, britų ir sovietų santykiai, Antrasis pasaulinis karas, Lenkija, Baltijos šalys, aneksija.

\section{A New Reading of Stafford Cripps's Memorandum of 22 October, 1940}

\begin{abstract}
This article significantly modifies and broadens the earlier version of the author's article published in the journal Dzieje Najnowsze in 1993. It elaborates on a British proposal for the Soviet government to balance bilateral relations at the time when the Soviet Union had already reached an agreement with the Third Reich. In order to weaken this agreement, the Government of Great Britain offered beneficial opportunities for the USSR, especially regarding the post-war settlement and countries of Eastern and Central Europe. In the new agreement, special attention had to be paid to Poland as well as to Estonia, Latvia and Lithuania and, finally, Romania. The author of the proposals was Sir Stafford Cripps, Great Britain's Ambassador to Moscow. In London, it was approved by the War Cabinet, and the British Ambassador was obliged by the Foreign Secretary to present it to the Soviet Government. The article analyses the course of the preparation and discussion of the document as well as the reaction of the Polish government in exile to British actions in achieving an agreement with Moscow. The memorandum, presented by Cripps to the Deputy
\end{abstract}

Received: $23 / 7 / 2021$. Accepted: $21 / 9 / 2021$

Copyright (C) 2021 Magdalena Hułas. Published by Martynas Mažvydas National Library of Lithuania

This is an Open Access article distributed under the terms of the Creative Commons Attribution Licence, which permits unrestricted use, distribution, and reproduction in any medium, provided the original author and source are credited. 
People's Commissar of Foreign Affairs Andrey Vyshinsky on 22 October 1940, remains an element of Great Britain's foreign policy towards the Soviet Union and, therefore, the article's author assumes that it ought to be more often referred to when investigating and explaining the genesis of the Anglo-Soviet Treaty of 26 May 1942. It has also to be taken account of when studying the fate of countries and nations of Eastern and Central Europe after the Second World War. (The article has been prepared at the request of the Editorial Board of the journal Relevant Tomorrow.)

Keywords: Stafford Cripps, Anglo-Soviet relations, Second World War, Poland, Baltic States, annexation.

1993 m. mokslo žurnale Dzieje Najnowsze buvo paskelbtas straipsnis apie memorandumą, kurị Didžiosios Britanijos ambasadorius Maskvoje Staffordas Crippsas 1940 m. spalio 22 d. perdave Sovietų Sąjungos užsienio reikalų liaudies komisaro pavaduotojui Andrejui J. Vyšinskiui ${ }^{1}$. Šis memorandumas, nors sovietai jị ir atmeté, mano nuomone, davè toną būsimiems britų ir sovietų santykiams. Jis parengtas tuo laikotarpiu, kai Didžioji Britanija stengėsi atpalaiduoti ryšius, siejusius Sovietų Sąjungą su Trečiuoju reichu, ir todèl sudarė visą paketą SSRS naudingų pasiūlymų, tarp jų (ir netgi būtent) pokario laikotarpiui. Po 1941 m. birželio 22 d., kai Sovietų Sąjunga vienaip ar kitaip atsidūrė sąjungininkų stovykloje, šio pasiūlymo aprèptis vis dar buvo atskaitos taškas, net jeigu nẻ viena iš šalių to nepabrèžè. Britų siūlomos nuolaidos turejo būti taikomos pirmiausia Vidurio ir Rytų Europos valstybių sąskaita, tad memorandumas atliko svarbų vaidmenį ne tik britų ir sovietų santykių istorijoje, bet ir šio regiono istorijoje.

Kai minètas straipsnis buvo rengiamas, S. Crippso memorandumas nebuvo nežinomas, tačiau tarp istorikų nesukèlė jo reikšmę atitinkančios reakcijos. Tiesa, Llewellynas Woodwardas išsamiai aptare Užsienio reikalų ministerijos (Foreign Office) (toliau - URM) dokumentus, atspindinčius S. Crippso akciją, tačiau ir tai yra būdinga jo Didžiosios Britanijos užsienio politikos per Antrąji pasaulinị karą oficialiai istorijai - apžvelgdamas dokumentus jis neteikè asmeninio vertinimo². Gabrielis Gorodetsky, S. Crippso diplomatinès misijos SSRS tema parašęs visą knygą, spalio memorandumui joje paskyrè vos keletą puslapių. Britu ambasadoriaus iniciatyvą jis įvertino kaip viltingą, tačiau teigè, jog dẻl URM konservatyvios politikos, kurią lèmé skirtingas politinès situacijos vertinimas, ji tapo „quite outdated $<\ldots$. Britain’s move was too late and not enthusiastic enough ${ }^{3{ }^{34}}$. Keleriais metais anksčiau iki pasirodant G. Gorodetsky knygai Harry Hanakảs paskelbė dviejų dalių straipsni apie S. Crippso misiją Maskvoje ${ }^{5}$. Jame memorandumui taip pat nebuvo skirta daug dèmesio. Iš tikruju H. Hanakas daugiau nei G. Gorodetsky teikè reikšmès Baltijos valstybių likimui, nulemtam šiame dokumente, bet panašiai kaip G. Gorodetsky nekreipè dèmesio i tai, kokias netektis turèjo patirti Lenkija. H. Hanako požiūriu, memorandumas - tai vienas iš S. Crippso bandymų pagerinti britų ir sovietų santykius etapų. Ir buvo aiškinamas jis paprastai - ne kaip Jungtinės Karalystès politikos sudedamoji dalis, o kaip individualus ambasadoriaus veiksmas, tik aprobuotas Londono ${ }^{6}$.

Sovietų šaltiniuose memorandumas apskritai neaptarinètas, pokyčių atsirado tik subyrëjus SSRS. Plačiai atvėrus Rusijos archyvus, be kita ko, pirmiausia buvo paskelbtas memorandumo vertimas rusų kalba (tokią - rusišką - versiją i teikè britų ambasadorius). Jis publikuotas kaip $1940 \mathrm{~m}$. spalio $22 \mathrm{~d}$. S. Crippso susitikimo su A. Vyšinskiu ataskaitos priedas $1995 \mathrm{~m}$. išleistame SSRS užsienio politikos dokumentų tome $e^{7}$. Nors dokumentas buvo paskelbtas, tyrinètas nedažnai. Palyginti išsamiai pateikdamas svarbesnių punktų turinị jị aptarè Vladimiras S. Lavrovas. Jis paskelbė komentarą, jog SSRS įsipareigojimai

Hułas, M. Memorandum Stafforda Crippsa z 22 października 1940 r. Polskie aspekty. Dzieje Najnowsze, 1993, t. 25, z. 4, s. 81-93. Woodward, L. British Foreign Policy in the Second World War, Vol. I. London: H. M. Stationery Office, 1970, p. 487-501.

"gerokai pasenęs $<\ldots>$ Britanijos žingsnis buvo pavèluotas ir nepakankamai entuziastingas" (čia ir toliau iš anglų k. - Aktualu rytoj vert.).

Gorodetsky, G. Stafford Cripps' Mission to Moscow, 1940-1942. Cambridge: Cambridge University Press, 1984, p. 76-80.

Žr. Hanak, H. Sir Stafford Cripps as British Ambassador in Moscow May 1940 to June 1941. The English Historical Review, 1979, Vol. 94, No. 370, p. 48-70; Hanak, H. Sir Stafford Cripps as Ambassador in Moscow, June 1941-January 1942. The English Historical Review, 1982, Vol. 97, No. 383, p. 332-344.

Plg., žr. The Foreign Office and the Kremlin: British documents on Anglo-Soviet Relations, 1941-45 / Edited, with an introduction, by Graham Ross. Cambridge: Cambridge University Press, 1984, p. 7 nn.

Документы внешней политики СССР. Том 23. Кн. 1.1 января - 31 октября 1940 2. Москва: Международные отношения, 1995, dok. 460, c. 701-705. 
memorandume liko tiksliai nuosekliai apibrežti, o britu įsipareigojimai suformuluoti „в туманных и неопределенных выражениях с разного рода оговорками о его обещаниях учитывать интересы СССР после победы над Германией ${ }^{{ }^{*} 9}$. Būtent šis komentaras pakartotas publikuojant memorandumą 2009 m. išleistame ambasadoriaus Ivano Majskio dienoraštyje ${ }^{10}$. Vis dèlto čia, kitaip nei V. Lavrovo straipsnyje, šis komentaras niekaip nepaaiškinamas - kokie turèjo būti britų issipareigojimai; pateikta tik Sovietų ịsipareigojimų santrauka. Anglosaksų literatūroje, netgi darbuose, tiesiogiai skirtuose temoms, susijusioms su memorandumu, šiam dokumentui taip pat nepakanka dèmesio. Antai $1999 \mathrm{~m}$. išleistoje S. Crippso biografijoje memorandumui skirta tiktai viena pastraipa ${ }^{11}$ (tačiau šiame fragmente pateikta informacija yra netiksli, tai aptarsime toliau); darbe, kuriame gvildenami 1939-1941 m. britų ir sovietu santykiai, S. Crippso memorandumui skirta puse puslapio $^{12}$; knygoje apie Turkijos vaidmeni britų ir sovietų santykiuose Antrajame pasauliniame kare nuorodų i šị dokumentą nepateikiama ${ }^{13}$; apie ji neužsimenama ir darbe, kuriame aptariama Didžiosios Britanijos (ir Jungtinių Valstijų) pozicija dèl Estijos, Latvijos ir Lietuvos ${ }^{14}$. Kiek daugiau demesio memorandumui skiriama lenkų istoriografijoje: turbūt daugiausia šia tema rašè Jacekas Tebinka, apie ji užsimindavo ir kiti autoriai ${ }^{15}$.

Vis dèlto vadinamasis S. Crippso memorandumas dažniausiai traktuojamas kaip atskiras dokumentas, o ne britų politikos dalis. Aptariant $1942 \mathrm{~m}$. gegužès $26 \mathrm{~d}$. britų ir sovietų sutarties genezę kaip anksčiausias atskaitos taškas vis dar nurodomas britų užsienio reikalų ministro (Secretary of State for Foreign Affairs) Anthony Edeno vizitas Maskvoje 1941 m. gruodị ir jam Josifo Stalino tada pateiktas pasiūlymas sudaryti sutartị. Šiomis aplinkybėmis atrodo pagrịsta priminti straipsnio, publikuoto mokslo žurnale Dzieje Najnowsze, nuostatas, papildant šio žurnalo (Aktualu rytoj / Relevant Tomorrow) straipsnyje išdèstytomis pastabomis ir atkreipiant dèmesị i porą naujų dokumentų.

Neabejotina, kad naujo pasiūlymo sudaryti sutartị dèl SSRS iniciatorius buvo S. Crippsas. Mūsų tikslas yra pabandyti išsiaiškinti, kaip jo koncepcijos atitiko Jo Karališkosios Didenybès (JKD) vyriausybès politinius planus, kaip dare jiems ịtaką ir kaip buvo keičiamos.

S. Crippsas nebuvo profesionalus diplomatas. Jis buvo politikas. Ir radikalių pažiūrų politikas, kurio nota bene pasirode pernelyg radikalios Darbo partijai (Labour Party) ${ }^{16}$. Buvo ịsitikinęs, kad yra būtina

„miglotai ir nekonkrečiai, su ịvairiomis išlygomis dèl pažadų atsižvelgti ị SSRS interesus po pergalès prieš Vokietiją“.

Лавров, В. С. Что скрывалось за приглашением В. М. Молотова осенью 1940 г. в Берлин и полетом Р. Гесса в мае 1941 г. в Англию. In: Международный кризис 1939-1941 г2.: от советско-германских договоров 1939 г. до нападения Германии на СССР. Москва: Права человека, 2006, с. 374.

10 Майский, И. М. Дневник дипломата, Лондон, 1934-1943: книга 2, часть 1: 4 сентября 1939 - 21 июня 1941 года / отв. ред. А. О. Чубарьян; сост. Н. В. Бойко, Е. В. Косырева, Л. В. Поздеева. Москва: Наука, 2009, с. 443, 79 išnaša.

11 Žr. Burgess, S. Stafford Cripps: A Political Life. London: Gollancz, 1999, p. 141.

12 Žr. Osborn, P. R. Operation Pike: Britain versus the Soviet Union, 1939-1941. Westport, CT and London: Greenwood Press, 2000. Autore pasinaudojo vertimu: Osborn, P. R. Brytyjskie plany ataku na ZSRR 1939-1941. Warszawa: Wydawnictwo Amber, 2007, p. 238-239. P. R. Osbornas S. Crippso memorandumo tema remiasi šaltiniu: Merritt, M. S. Between Churchill and Stalin: The Soviet Union, Great Britain, and the Origins of the Grand Alliance. Chapel Hill: University of North Carolina Press, 1988.

13 Žr. Tamkin, N. Britain, Turkey and the Soviet Union, 1940-45: Strategy, Diplomacy and Intelligence in the Eastern Mediterranean. New York: Palgrave Macmillan, 2009.

14 Žr. Piirimäe, K. Roosevelt, Churchill, and the Baltic Question: Allied Relations during the Second World War. New York: Palgrave Macmillan, 2014.

15 Žr. Tebinka, J. Polityka brytyjska wobec problemu granicy polsko-radzieckiej 1939-1945. Warszawa: Wydawn, Neriton, 1998, s. 115123; Wandycz, P. Z Piłsudskim i Sikorskim. August Zaleski, minister spraw zagranicznych w latach 1926-1932 i 1939-1941. Warszawa: Wydawn. Sejmowe, 1999, s. 222-224; Dębski, S. Między Berlinem a Moskwą: stosunki niemiecko-sowieckie 1939-1941. Warszawa: Polski Instytut Spraw Międzynarodowych, 2003, s. 419-420; Berska, B. Kłopotliwy sojusznik. Wpływ dyplomacji brytyjskiej na stosunki polsko-sowieckie w latach 1939-1943. Kraków: Księgarnia Akademicka, 2005, s. 67-75.

16 Stafford Cripps (1889-1952), britų kairysis politikas, iki 1939 m. birželio - Darbo partijos (Labour Party) narys, iš kurios pašalintas kaip sąveikos su Didžiosios Britanijos komunistų partija šalininkas. Parašytos kelios jo biografijos: Cooke, C. A. The Life of Richard Stafford Cripps. London: Hodder and Stoughton, 1957; Estorick, E. Stafford Cripps: Master Statesman. New York: The John Day Company, 1949; Burgess, S. Stafford Cripps: A Political Life; Clarke, P. The Cripps Version: The Life of Sir Stafford Cripps, 1889-1952. London: Allen Lane, The Penguin Press, 2002. S. Crippso misijos tema yra šaltiniuose, nurodytuose 4 ir 5 išnašoje bei: Stafford Cripps in Moscow, 1940-1942: Diaries and Papers / Ed. G. Gorodetsky. London and Portland, OR: Vallentine Mitchell, 2007. 
sureguliuoti santykius su Sovietų Sajunga, ir anksčiau skelbėsi pasiryžęs vykti ił Maskvą ir dirbti šia kryptimi. $1939 \mathrm{~m}$. birželio ir liepos sandūroje tokị pasiūlymą pateike tuometiniam užsienio reikalų ministrui lordui Edwardui Halifaksui, tačiau šis atsake, jog - kaip pažymejjo S. Crippsas dienoraštyje "at the moment they could not use my services! ${ }^{17{ }^{118}} .1939 \mathrm{~m}$. rugsèji jis pakartojo pasiūlymą ir galiausiai $1940 \mathrm{~m}$. birželio $12 \mathrm{~d}$. atvyko ị Maskvą kaip naujasis ambasadorius, nors pirminis JKD vyriausybės tikslas buvo siųsti ji j SSRS išskirtinai kaip specialųji pasiuntinị atlikti - kaip apibūdinta - „exploratory mission“ („žvalgomąją misiją") ${ }^{19}$. Tik po kone ultimatyvaus sovietų spaudimo sutikta, kad S. Crippsas vyktų í Maskvą kaip ambasadorius ${ }^{20}$.

Mūsų domèjimosi objektas yra ne visa jo misija, o tik pasiūlymai, pateikti Sovietų vyriausybei $1940 \mathrm{~m}$. spalio $22 \mathrm{~d}$. Tiesioginè šių pasiūlymų priežastis buvo tos pačios krypties vokiečių iniciatyva, t. y. palaikyti artimesnius ryšius su SSRS. Spalio $13 \mathrm{~d}$. buvo numatytas Vokietijos ambasadoriaus Sovietų Sąjungoje Friedricho Wernerio von der Schulenburgo grịžimas iš Berlyno ị Maskvą, ir būtent tą dieną S. Crippsas išsiunte i URM šifruotą pranešimą, kuriuo perspèjo, kad Vokietija gali pateikti „attractive offers for Russia for her hostile neutrality to Great Britain and Turkey or for her participation against Turkey ${ }^{21 \text { " }}$. Britu ambasadorius buvo ịsitikinęs, jog tai yra paskutinė akimirka palenkti Sovietų Sąungą prie britų, o vienintelis argumentas, kuris galètų SSRS tuo įtikinti, būtų „,some attractive offer as to their post-war position $^{22 “}$. Šio pasiūlymo esmę S. Crippsas pateikè savo pranešimo dvyliktame paragrafe, kuris skambejjo taip:

Is it not possible in order to make a real effort to change their [Soviet Government's] policies for us to inform them that in the event of behaving to us in as friendly a way as they behave to Germany and substituting a benevolent neutrality at least towards Turkey and Iran in event of either of them being attacked, we would (a) guarantee in the event of our being victorious to consult with them fully on post-war settlement of Europe and Asia in association with other victorious powers. (b) Not to form or enter any anti-Soviet alliance after the war. (c) For the time being till after the war (gr[ou]p undec[iphered]) their de facto sovereignty of the Baltic States and part of Poland, Bessarabia and Bukovina they have occupied. (d) Arrange to supply them with articles they require and we can spare for arming themselves against Axis should they be attacked. (e) Guarantee that they will not be attacked from the south from Iran or Turkey and especially that Baku will not be attacked from these countries by us or any of our Allies. ${ }^{23,24}$

S. Crippso nuomone, sovietų pritarimą priimti šiuos slaptus politinius pasiūlymus liudytų prekybos sutarties sudarymas. Ir tik jeigu ją pasirašius nekiltų pavojingų reakcijų iš Ašies valstybių, Didžioji Britanija ir Sovietų Sąjunga turèjo pasirašyti nepuolimo paktą - panašų i tą, kurị SSRS sudarè su Vokietija. S. Crippsas prašè skubiai atsiliepti dèl šių pasiūlymų. Lordas Halifaksas supažindino su S. Crippso pasiūlymais Karo kabineto narius ir pateike rekomendaciją: „there was good deal to be said for acting on the

„šiuo metu jie negalètų pasinaudoti mano paslaugomis!“.

18 Stafford Cripps' Confidential Diary, July 3 [1939]. In: Bodleian Library, Oxford (toliau: BL), Sir Stafford Cripps' Papers (depozyt Nuffield College), (toliau: SC), SC-5.

19 Karo kabineto posėdis, 18.05.1940, pkt. 13. In: The National Archives, Kew (tolau: TNA), War Cabinet: Minutes and Conclusions of the War Cabinet, WM Series (CAB 65), CAB 65/7/22, WM (40)127.

Karo kabineto posedis, 31.05.1940, pkt. 9. TNA, CAB 65/7/44, WM (40)149.

„patrauklių pasiūlymų Rusijai mainais už jos priešišką neutralumą Didžiosios Britanijos ir Turkijos atžvilgiu arba už nukreiptus prieš Turkiją veiksmus“.

„kokị nors patrauklų pasiūlymą, susijusį su jų pozicija karui pasibaigus“.

3 „Kaip reali pastanga pakeisti jų [Sovietų vyriausybès] politiką galètų būti informavimas, kad jeigu jie mums būtų draugiški (taip, kaip elgiasi Vokietijos atžvilgiu) ir laikytųsi draugiško neutralumo bent jau Turkijos ir Irano atžvilgiu, jeigu bet kuri iš šalių būtų užpulta, mes (a) užtikrintume, jog, mums esant nugalejjusiąja šalimi, išsamiai tartumès su jais dèl pokario Europos ir Azijos sureguliavimo kartu su kitomis nugalejjusiomis šalimis; (b) karui pasibaigus, neformuotume jokių antisovietinių aljansų ir ị tokius aljansus nestotume; (c) iki kol pasibaigs karas [nę̧skaitoma] jų de facto suverenitetą Baltijos valstybèse ir jų okupuotoje Lenkijos dalyje bei Besarabijoje ir Bukovinoje; (d) pagal galimybes organizuotume prekių, jiems būtinų ginantis nuo Ašies šalių, tiekimą; e) užtikrintume, kad jie nebus puolami iš pietų puses iš Irano arba Turkijos teritorijos, ir ypač kad iš šių šalių teritorijos mes arba mūsų sąjungininkai nepulsime Baku."

24 S. Crippso pranešimas, 13.10.1940, No. 865. TNA, Foreign Office: General Correspondence (FO 371), FO 371/24845, N.6875/30/38. 
lines suggested by Sir Stafford Cripp ${ }^{25 \times 26}$. Kitą dieną, t. y. spalio 15-ąją, S. Crippso pranešimas ir parengtas URM atsakymo projektas buvo aptarti Karo kabinete. Buvo pritarta instrukcijos, skirtos S. Crippsui, turiniui ir dar tą pačią dieną ji išsiųsta i Maskvą ${ }^{27}$. E. Halifaksas joje ịpareigojo ambasadorių pradèti atitinkamus pokalbius su Sovietų vyriausybe, tačiau nurodè būti atsargiam prisiimant ịsipareigojimus. Jis pabrèžè, jog Sovietų Sąunga privalanti „give some practical proof of benevolent neutrality towards Turkey and $\operatorname{Iran}^{28 “}$. Papildomai aiškino, jog galimas pritarimas dèl pokario konsultacijų su Sovietų Sąjunga nereiškia pasirengimo pripažinti sovietų požiūrị i Europos ir Azijos ateitị. Be to, manė, kad ịsipareigojant nedalyvauti jokioje sąungoje, nukreiptoje prieš SSRS, būtina sąlyga yra sovietų ịsipareigojimas nesikišti i britų interesus - nesvarbu, tiesiogiai ar netiesiogiai (per revoliucinę agitaciją). Labiausiai mus dominančiame instrukcijos punkte pabrèžta:

We already recognise that Soviet Government are in de facto control of Baltic States and occupied parts of Poland and Roumania, and I see no objection to your telling them that we shall continue to act on this assumption. I obviously could not, however, agree to any statement implying de jure recognition or gravely compromising post-war position; and I fear that this is what they may want... ${ }^{29}$

Taigi Simonas Burgessas klysta rašydamas, kad S. Crippsas iš E. Halifakso gavo teisę laisvai veikti ir kad pateike Molotovui greitomis savo paties parengtą memorandumą (sic!), o Karo kabinetas tik buvo apie tai informuotas (supraskime - post factum) ${ }^{30}$. Karo kabinetas apie S. Crippso pasiūlymą buvo informuotas iš anksto ir jam pritare, ir tik gavęs „žalią šviesą“ ambasadorius spalio 17-ąją papraše susitikti su Molotovu ${ }^{31}$. Tada jis nežinojo, jog tą pačią dieną Schulenburgas ịteikè Molotovui spalio 13 d. parašytą Ribbentropo laišką, kuriuo buvo kviečiama atvykti vizito ị Berlyną ${ }^{32}$. S. Crippsas, nesulaukęs jokio atsakymo, savo prašymą pakartojo spalio 21 d. - tą dieną, kai Molotovas prièmé kvietimą atvykti į Berlyną̧ ${ }^{33}$. Ir tik kitą dieną, t. y. spalio $22 \mathrm{~d}$., S. Crippsas gavo galimybę susitikti, tačiau ne su Molotovu, o tik su jo pavaduotoju A. Vyšinskiu ${ }^{34}$.

Per susitikimą S. Crippsas liaudies komisaro pavaduotojui ịteikẻ dokumentą apie britų pasiūlymus santykiams su Sovietų Sąjunga suderinti. Ataskaitą apie ịvykusị pokalbị kartu su A. Vyšinskiui pateikto memorandumo santrauka $S$. Crippsas išsiunte ị Londoną naktị iš spalio 22-osios ị 23-iąją pranešimais Nr. 911, 912 ir $913^{35}$. Kaip matyti iš telegramos Nr. 911, pateiktasis memorandumas buvo rusiškas dokumento, parengto anglų kalba, vertimas. Tai padaryta ne iš mandagumo, o siekiant apsidrausti. Bent jau tokị vertimą galima aptikti spalio $31 \mathrm{~d}$. S. Crippso telegramoje, kurioje ambasadorius patikino, jog A. Vyšinskis nemate angliškos teksto versijos, aiškindamas:

„būtų galima pateikti daug argumentų pritarti sero Staffordo Crippso siūlomiems veiksmams“.

Karo kabineto posedis, 14.10.1940. TNA, CAB 65/9/32, WM (40) 270.

Žr. Karo kabineto posedis, 15.10.1940. TNA, CAB 65/9/33, WM (40) 271; telegram FO do S. Crippsa, 15.10.1940, No 641. TNA, FO 371/24845, N.6875/30/38.

28 „praktiškai įrodyti savo draugišką neutralumą Turkijos ir Irano atžvilgiu“.

29 „Mes jau pripažistame, kad Sovietų vyriausybè de facto kontroliuoja Baltijos valstybes bei okupuotas Lenkijos ir Rumunijos dalis, ir aš neprieštarauju, kad jiems pasakytumète, jog mes ir toliau veiksime remdamiesi šia prielaida. Aš, žinoma, nepritarčiau jokiam teiginiui, išreiškiančiam de jure valdymo pripažinimą arba šiurkščiai kompromituojančiam pokarinị statusą; ir manau, kad būtent to jie gali norèti..."

30 Burgess, S. Stafford Cripps: A Political Life, p. 141.

Telegram S. Crippsa do Londynu, 22.10.1940, No. 909. TNA, FO 371/24845, N.6875/30/38.

Akten zur Deutschen Auswärtigen Politik. 1918-1945, Serie D: 1937-1945, Band XI. 1, Bonn 1964, dok. 176, p. $248-253$.

Ibidem, dok. 211, p. 300-301.

34 S. Crippsas buvo linkęs manyti, kad sunkumai, kuriuos jis patyrẻ Maskvoje, kilo dẻl asmeninių Molotovo (provokiškų) simpatijų ir (antibritiškų) išankstinių nuostatų. Žr. S. Cripps do Hughe Knatchbull-Hugessena, 23.10.1940. BL, SC-5. Šią problemą kitaip matė Orme Sargentas, kuris, komentuodamas Didžiosios Britanijos ambasadoriaus Maskvoje situaciją, 19400628 rašè: „I am sorry for Sir S. Cripps, who is now entering the humiliating phase which all British negotiators in Moscow have to go through when they are simply kept waiting on the doormat until such time as the Soviet Government consider it desirable, as part of their policy of playing off one Power against the other, to take notice of H. M. Representatives...“ („Man gaila sero S. Crippso, priejusio pažeminimo etapą, kurị pereina visi britų derybininkai Maskvoje, kai jie paprasčiausiai verčiami laukti už durų, kol Sovietų vyriausybẻ, vykdydama jègų kiršinimo politiką, atkreipia dèmeși ị Jo Didenybės pasiuntinius..."), cit. pagal: Hanak, H. Sir Stafford Cripps as British Ambassador in Moscow May 1940 to June 1941, p. 59.

35 S. Crippso pranešimai ị Londoną, 22.10.1940, No 911, 912, 913. TNA, FO 371/24845, N.6875/30/38. 
As we never correspond officially in Russian, there should be no difficulty at the appropriate time, if they raise points, in satisfying them that this document was never intended to, and does not, constitute a text and that actual English words of such a text when drawn up may not be identical with those translated into Russian in the proposals submitted, though substance will be same. ${ }^{36,37}$

Tiesa, nors S. Crippsas pasinaudojo šiais argumentais jau memorandumą įteikęs, aiškindamas, kodèl nepaisè iš URM gautų instrukcijų (apie tai - toliau), vis dèlto galima pripažinti, kad ị juos buvo atsižvelgta ir anksčiau. Kaip aiškejja iš A. Vyšinskio ataskaitos apie susitikimą su S. Crippsu, britų ambasadorius, itteikdamas memorandumą rusų kalba, prašè, kad šis tekstas būtų laikomas neoficialiu oficialaus angliško dokumento vertimu ${ }^{38}$. Itteikto memorandumo turinį ilgokai žinojome iš jo angliškos versijos, remdamiesi tik nurodytomis trimis $\mathrm{S}$. Crippso telegramomis ${ }^{39}$. Rusiška versija nebuvo žinoma, ji neatsirado nei tarp URM dokumentų, nei tarp S. Crippso popierių - tiek saugotų The National Archives (CAB 127/66), tiek Bodleian Library Oksforde. Tačiau, kaip minèta, 1995 m. pasirodžiusiame serijos Документы внешней политики СССР 1940-1941 m. birželio mèn. laikotarpio pirmame tome greta A. Vyšinskio ataskaitos apie pokalbị su S. Crippsu paskelbtas rusiškas memorandumo tekstas. Šie dokumentai yra iš Apxuв Внешней Политики Российской Федерации fondo. Aptardami britų pateiktų pasiūlymų turinį naudosimès ir rusiška, ir angliška versijomis.

S. Crippso pasiūlymų esmę sudarė Jungtinès Karalystės ir Sovietų Sąjungos pasikeitimas įsipareigojimais. Sovietų šalis turẻjo ịsipareigoti: a) išsaugoti neutralumą Didžiosios Britanijos atžvilgiu (tokị pat viltingą kaip ir Vokietijos atžvilgiu ${ }^{40}$ ); b) rodyti mandagų neutralumą Turkijos ir Irano atžvilgiu, ypač jeigu ịsipainiotų $\mathfrak{i}$ karinius veiksmus su Ašies valstybe; c) suteikti paramą Kinijos vyriausybei jos kovoje prieš japonų agresiją, nesudarydama sutarčių su Japonijos vyriausybe; d) pasirašius britų ir sovietų prekybos susitarimą ir nesulaukus priešiškos reakcijos iš Ašies valstybių arba Japonijos šio susitarimo atžvilgiu, su Jo Didenybès vyriausybe sudaryti nepuolimo sutartị, panašią į tą, kurią SSRS sudare su Vokietija. Britų šalis ịsipareigojo: a) konsultuotis su SSRS del pokario tvarkos Europoje ir Azijoje ${ }^{41}$ (apsidrausdama, jog tai nereiškia pažado iš anksto priimti sovietų požiūrị); b) nekurti (ir nestoti) pokariu ị jokią sąjungą, nukreiptą prieš Sovietų Sąungą, su sąlyga, jog SSRS susilaikys nuo bet kokios (tiesioginès ar netiesioginès) priešiškos akcijos, nukreiptos prieš JKD vyriausybès interesus; c) „[t] o recognise, until consultations under 2 (a) above take place, de facto sovereignty of the U.S.S.R. in Estonia, Latvia, Lithuania, Bessarabia and Northern Bukovina and those parts of former Polish State now under Soviet control ${ }^{42{ }^{433}}$; d) pagal galimybes tiekti prekes, reikalingas SSRS gynybai nuo kaimyninių valstybių puolimo; e) užtikrinti, jog iš Turkijos arba Irano teritorijos nebūtų surengta jokio - nei Didžiosios Britanijos, nei dabartinių arba būsimų sajungininkų - puolimo prieš SSRS.

36 „Mes niekada oficialiai nebendraujame rusiškai, todèl jeigu kada nors jie iškeltų šį klausimą, nebūtų sunku juos patikinti, jog šis dokumentas nebuvo sumanytas kaip oficialus tekstas ir jis toks nèra, ir jog tokio teksto, jei jis būtų parengtas, angliški žodžiai gali nebūti tapatūs išverstuose ị rusų kalbą pateiktuose pasiūlymuose vartojamiems žodžiams, nors esmè nebūtų pasikeitusi."

37 S. Crippso pranešimas ị Londoną, 31.10.1940, No. 944. TNA, FO 371/24845, N.7046/30/38.

38 Документы внешней политики СССР. Том 23. Кн. 1.1 января - 31 октября 1940 г., с. 701.

39 Žr. Tebinka, J. Polityka brytyjska wobec problemu granicy polsko-radzieckiej 1939-1945, s. 117, przyp. 208. Memorandumo tekstas (anglų kalba) su sutrumpinta izžanga pateikiamas kaip priedas prie S. Crippso misijos santraukos, kurią $1941 \mathrm{~m}$. kovo $17 \mathrm{~d}$. išsiuntė per Jo Didenybès ambasadą Maskvoje ị URM.

40 Versijoje, publikuotoje „Документы внешней политики СССР“, kalbama apie geranorišką SSRS neutralumą Turkijos, o ne Vokietijos atžvilgiu, o tai reikia suprasti kaip spausdinimo klaidą. Žr. Документы внешней политики СССР. Том 23. Кн. 1. 1 января 31 октября 1940 г., с. 704.

${ }_{41}$ Mums žinomoje rusiškoje dokumento versijoje angliška frazè „to consult with the Soviet Government, in association with the other powers...“ („konsultuotis su Sovietų vyriausybe kartu du kitomis šalimis“) buvo sustiprinta ir igavo tokią formą: „консультировать в полной мере с Советским правительством наравне с другими державами... [рaryškinta M. Н.]“ (išsamiai konsultuotis su Sovietų vyriausybe kartu su kitomis šalimis"). Deja, nepavyko nustatyti, kas išverte dokumentą i rusų kalbą; galbūt tuometinis Didžiosios Britanijos ambasados Maskvoje vertėjas Charlesas Dunlopas.

42 „iki prasidedant konsultacijoms 2 (a) nurodytais klausimais, pripažinti SSRS faktinị suverenitetą Estijoje, Latvijoje, Lietuvoje, Besarabijoje ir Šiaurès Bukovinoje bei tose buvusios Lenkijos valstybès dalyse, kurios dabar yra kontroliuojamos Sovietų Sajungos".

${ }_{43}$ Rusiškoje versijoje prieštaringiausios šios pastraipos formuluotès buvo tokios: „de facto власть Советского Союза“ (Sovietų Sąjungos de facto valdymas), „в тех частях бывшего Польского государства $<\ldots>$ под Советским главенством. (buvusios Lenkijos valstybès teritorijose $\langle\ldots\rangle$, kurias valdo Sovietų Sąjunga) [paryškinta - M. H.]“. 
A. Vyšinskis pareiškè, kad dèl pateiktų dokumente pasiūlymų reikšmingumo negali pateikti pozicijos nesuderinęs su vyriausybe. Prie klausimo grižta spalio 26 d.: liaudies komisaro pavaduotojas tą dieną informavo britų ambasadorių, jog Sovietų vyriausybė įvertino pateiktus pasiūlymus kaip svarbius, reikalingus nuodugnesnès analizès, ir pasistengė gauti iš $\mathrm{S}$. Crippso papildomą paaiškinimą ${ }^{44}$. Joks iš jo klausimų tiesiogiai neaprèpe „, de facto suvereniteto pripažinimo“, kitaip tariant, punkto, kuris kèlè daugiausia diskusijų Londone.

Pirmuosiuose URM komentaruose dèl S. Crippso memorandumo teigta, kad jo turinys atitinka duotas ambasadoriui instrukcijas, o ị porą pastebètų neatitikimų nekreipta dèmesio. Spalio $24 \mathrm{~d}$. komentare URM Šiaurès šalių skyriaus vadovas Laurence Collier, tiesa, rašè, jog dèl S. Crippso pavartotos formuluotès „de facto sovereignty“, reiškiančios daugiau negu instrukcijoje pavartota formuluotè „de facto control", Lenkijos (ir Amerikos) vyriausybė gali prieštarauti, tačiau jis nepaisẻ fakto, kad britų ambasadorius savo memorandume pavartojo formuluotę „, former Polish State ${ }^{{ }_{45}}$. O juk tai prieštaravo ne tiktai tarptautinès teisès principams, bet ir britų užsienio politikos nuostatoms. Tik vèliau buvo atkreiptas L. Collier dèmesys ị S. Crippso pavartotą formuluotę, bet ir tada jis teigè, jog taip tikriausiai nutiko dèl nekruopštaus redagavimo, o ne dèl S. Crippso politinių pažiūrų ${ }^{46}$. Jis neįžvelgè S. Crippso pavartotos formuluotès reikšmès sovietinei šaliai ir kaip bus sunku ją pašalinti - ne dèl žodžių, bet norint pakeisti apibrèžtas britų nuolaidų ribas.

S. Crippso pranešimai iš Maskvos vis dèlto sukèlè nerimo premjerui Winstonui Churchilliui ir jis pranešimo Nr. 913 punkto, kuriame aptariama „de facto sovereignty“, paraštẻje uždavẻ klausimą: „Foreign Secretary. Has Sikorski been consulted at all about this kind of line? WSC, 26[?].X ${ }^{47}$. Atsakydamas E. Halifaksas pasistengè problemą kiek įmanoma sumažinti, informavo premjerą, kad bus atkreiptas ambasadoriaus demesys i skirtumus tarp instrukcijos ir jos igyvendinimo, ir patikino, jog leksiką bus stengiamasi pakeisti. Pabrèžè, jog tai nebus lengva, nes sovietai kaltins bandant „praskiesti“ pirminị pasiūlymą. Atsakymo fragmentą apie Lenkijos vyriausybę verta pacituoti ištisai. E. Halifaksas rašè:

Sikorski has not been consulted about these discussions, but the Polish position was, as you will have seen, sufficiently safeguarded by our instructions to Cripps, which limited our recognition of the 'de facto' position till the end of the war. Sikorski has always, I think, been ready to distinguish between Russian-occupied, and German-occupied Poland. .8, $49^{2}$

Nuomonè, pareikšta šiame paskutiniame sakinyje, tikriausiai buvo suformuluota remiantis iš dalies asmeniniais E. Halifakso įsitikinimais, iš dalies ankstesniu jo bendravimu su W. Sikorskiu. Mat prieš metus, 1939 m. spalio 26 d., Lordų rūmuose E. Halifaksas komentuodamas rugsėjo 17 d. sovietų agresiją prieš Lenkiją pasakè, kad šitaip SSRS pasiekè sieną, dar anksčiau siūlytą lordo Curzono ${ }^{50}$. Po to Lenkijos šalis premjero W. Sikorskio pavedimu $1940 \mathrm{~m}$. birželio 19 d. E. Halifaksui ịteikè memorandumą dèl lenkų ir sovietų santykių, vadinamą Litauerio memorandum (po kelių dienų jis buvo atšauktas) ${ }^{51}$. Be to, birželio 19 d. abu politikai buvo susitikę pokalbio, per kurị W. Sikorskis esą pasakęs, jog būtų linkęs teigiamai atsakyti ị Sovie-

A. Vyšinskis per pokalbị kelis kartus pabrèžè, jog sovietų šalis nori, kad S. Crippso paaiškinimai būtų visiškai patvirtinti Didžiosios Britanijos vyriausybès, žr. S. Crippso pranešimą, informuojantị apie pokalbio eigą: 26.10.1940, No 925. TNA, FO 371/24848, N.6984/40/38. Toks pritarimas perduotas telegrafu: FO - S. Crippsui, 29.10.1940, No 719. Ibidem.

45 L. Collier komentaras apie S. Crippso pranešimus: Nr 911-913, 24.10.1940. TNA, FO 371/24845, N.6875/30/38.

6 L. Collier H. Seymourui (URM pasekretoriaus pavaduotojui), 25.10.1940. Ibidem.

„Užsienio reikalų ministras. Ar buvo iš viso tariamasi su Sikorskiu dèl tokios pozicijos?“.

48 „Su Sikorskiu dèl šių svarstymų tariamasi nebuvo, tačiau, kaip matète, Lenkijos poziciją gana apsaugo mūsų nurodymai S. Crippsui, nustatantys, kad mūsų de facto statuso pripažinimas galioja tik iki pasibaigs karas. Sikorskis, mano manymu, visada buvo pasirengęs skirti Rusijos okupuotąją ir Vokietijos okupuotąją Lenkiją."

49 Halifax do W. S. Churchilla, 26.10.1940. Ibidem.

50 Žr. Poland in the British Parliament. 1939-1945. Vol. I: British Guarantees to Poland to The Atlantic Charter (March 1939 - August 1941). Compiled and edited by W. Jędrzejewicz with the assistance of P. C. Ramsey. New York: Jozef Pilsudski Institute of America for Research in the Modern History of Poland, 1946, p. 356. Dèl E. Halifakso pareiškimo lenkai, suprantama, smarkiai prieštaravo, žr. Tebinka, J. Polityka brytyjska wobec problemu granicy polsko-radzieckiej 1939-1945, s. 87-91.

51 Plačiau apie tai žr. Cienciala, A. M. The Question of the Polish-Soviet Frontier in 1939-1940: The Litauer Memorandum and Sikorski’s Proposal for Re-establishing Polish-Soviet Relations. The Polish Review, 1988, Vol. 33, No. 3, p. 295-323. 
tụ bandymus su juo susisiekti: „on condition that the question of the eastern frontier of Poland was freely discussed $^{52{ }^{263}}$. Ši nuostata atsirado tuo metu rengtoje S. Crippsui instrukcijoje, bet E. Halifaksas nusprende išbraukti ši fragmentą teigdamas, kad lenkai tikriausiai dar nèra pasirengę tiek daug priimtij ${ }^{54}$.

Vis dèlto grịžkime prie $1940 \mathrm{~m}$. spalio ịvykių. E. Halifaksas, nepaisydamas įspejimų, dèl kurių pats rašè W. Churchilliui, pripažino, kad vertètų pabandyti sušvelninti S. Crippso teiginius. Pranešime ambasadoriui siūlè atsisakyti žodžių „suverenitetas“ (sovereignty) ir „buvusi“ teigdamas: „In case of absolute necessity we might have to accept 'sovereignty' but, in view of our relations and arrangements with Poland, we cannot in an international agreement speak of 'former Polish State. ${ }^{55{ }^{4} 56}$ S. Crippso atsakymas parodè, jog, priešingai, nei teigè L. Collier, žodžiai buvo pavartoti ne atsitiktinai ar dèl neatidumo, o atspindèjo ambasadoriaus pažiūras. Aiškindamas savo pavartotą formuluotę „suverenitetas de facto“, S. Crippsas ypač atkreipe dėmeși, kad vartojo ją tarp savo pasiūlymų, pateiktų URM spalio $12 \mathrm{~d}$. ir kad tuo metu dèl jos neprieštarauta. Dar argumentavo, jog „Russian translation given to Vyshinsky employed however a somewhat vague word 'vlast' meaning power or (?authority) and there will be no great difficulty in explaining to the Soviet authorities that this is a translation of the English word 'control' for which there is no exact Russian equivalent ${ }^{57 “}$. O dèl apibūdinimo „buvusi Lenkijos valstybe““ JKD ambasadorius tvirtino: „I was not aware that His Majesty's Government desired to maintain fiction that former Polish state (as distinct from the Government) still exists de facto. ${ }^{58 “}$ S. Crippsas, išsilavinęs teisininkas, ir toliau manė, jog apibūdinimas „buvusi“ kalbant apie Lenkijos valstybę yra teisingas, nors pripažino, kad vartoti šią formuluotę oficialiame tekste psichologiniu atžvilgiu būtų netikslinga. Taigi jis taip pat siūlè pakeisti ją teiginiu, kuriam pritartų britai ir kuris nekelia tokio prieštaravimo kaip „Soviet-occupied Poland“ („Sovietų okupuota Lenkija“), o būtent: „those White Russian and Ukrainian districts which at the date of outbreak of war were part of the Polish State ${ }^{59{ }^{60}}$.

Ir tik šitaip S. Crippsui atskleidus asmenines pažiūras URM pradèta aktyviai keistis nuomonèmis. Fitzroy Macleanas tvirtino, kad ambasadoriaus pažiūros ị suvereniteto ir valstybių tęstinumo klausimus neatitinka tarptautinès teisės principų. Jis pripažino, kad S. Crippso siūloma nauja formuluotès versija kelia ne mažiau abejonių nei „former Polish State“ („buvusi Lenkijos valstybë), ir paprašè pakomentuoti URM teisès patarẻją Williamą Malkiną, kurio anksčiau tuo klausimu nebuvo atsiklausta ${ }^{61}$. W. Malkinas pritare F. Macleano nuomonei ${ }^{62}$. Kartu buvo suderinta nauja tinkamos formuluotès versija ir apie tai S. Crippsas lapkričio $8 \mathrm{~d}$. buvo informuotas pranešimu. Jam nurodyta suteikti aptariamam fragmentui tokị skambesị: „To recognise until consultations under 2(a) above take place de facto control of Soviet Government in Estonia, Latvia, Lithuania, Bessarabia and Northern Bukovina, and those parts of Poland now under Soviet administration. ${ }^{63 “}$ Ši formuluote papildomai paaiškinta: „We must avoid any phrase which might imply that last-named territories are in law no longer part of Polish State. ${ }^{64^{465}}$

„su sąlyga, kad bus laisvai svarstomas Lenkijos rytų pasienio klausimas“.

E. Halifakso pokalbio su W. Sikorskiu ataskaita, 19.06.1940. TNA, FO 371/24482, C.7880/7177/55.

A. Beviro pažyma W. S. Churchilliui, 24.06.1940. TNA, Prime Minister's Office: Operational Papers (PREM 3), PREM 3/395/1.

„Jeigu tai būtų absoliučiai būtina, galbūt turètume sutikti su „suverenitetu“, tačiau atsižvelgdami ị mūsų santykius ir susitarimus su Lenkija negalime tarptautinejje sutartyje kalbèti apie „buvusią Lenkijos valstybę.“

6 URM pranešimas S. Crippsui, 30.10.1940, No. 720. Ibidem.

„Vyšinskiui įteiktame rusiškame vertime vis tik buvo kažkiek miglotas žodis „,last“", reiškiantis „galią“ arba (?,,valdžią“), ir būtų nesunku Sovietų vyresnybei paaiškinti, kad tai yra tikslaus rusiško atitikmens neturinčio angliško žodžio „kontroliavimas“ vertinys“.

58 „Nežinojau, kad Jo Didenybès vyriausybė tiki prasimanymu, jog buvusi Lenkijos valstybė (skirtingai negu vyriausybė) vis dar faktiškai egzistuoja."

59 „Baltosios Rutenijos ir Ukrainos sritys, kurios, kilus karui, buvo Lenkijos valstybės sudètyje“.

60 S. Crippso pranešimas ị Londoną, 31.10.1940, No 944. TNA, FO 371/24845, N.7046/30/38.

F. Macleano pažyma, 3.11.1940. Ibidem.

W. Malkino pažyma, 4.11.1940. Ibidem.

63 „Iki prasidedant konsultacijoms 2 (a) nurodytais klausimais, pripažinti, kad Sovietų vyriausybè de facto kontroliuoja Estiją, Latviją, Lietuvą, Besarabiją ir Šiaurès Bukoviną bei tas buvusios Lenkijos valstybès dalis, kurias dabar valdo Sovietų Sąunga.“

64 „Turime vengti bet kokios frazès, leidžiančios suprasti, kad minètos teritorijos juridiškai nebèra Lenkijos valstybės dalis.“

65 URM pranešimas S. Crippsui, 8.11.1940, No. 760. Ibidem. 
Britams tariantis, kaip galutinai suformuluoti britų ir sovietų susitarimą, sovietai buvo linkę ji visiškai atmesti. Lapkričio 2 d. susitikęs su S. Crippsu A. Vyšinskis jam priekaištavo, kad britai, kitaip, nei deklaruoja, nesuinteresuoti pagerinti santykių su Sovietų Sąjunga, o paskui pridūrè, jog dèl spalio $22 \mathrm{~d}$. memorandumo jokių papildomų klausimų nèra ${ }^{66}$. Tai buvo ženklas, kad sovietų valdžia garantijų savo interesams ieško kitur. Lapkričio $9 \mathrm{~d}$. Vokietijos radijas pranešè apie Molotovo vizitą Berlyne, kitą dieną Maskvos spauda informavo apie jo išvykimą ${ }^{67}$. Skubomis URM parengtame pranešime $\mathrm{S}$. Crippsas pažymejjo, jog užsienio reikalų liaudies komisaras tikriausiai informavo vokiečius apie britų pasiūlymą, kad gautų naudingesnes susitarimui sąlygas - mat S. Crippsas neturèjo jokių abejonių, jog toks susitarimas iš anksto parengtas ${ }^{68}$. Kitą dieną S. Crippsas vèl susitiko su A. Vyšinskiu ir ėmèsi kitokios derybų taktikos. Jis bandė daryti spaudimą pabrèždamas, kad britų pasiūlymas nèra neterminuotas, o draugiškas neutralumas, SSRS siūlomas Didžiajai Britanijai, vèliau neturès tokios vertès, kokią turètų tuo metu ${ }^{69}$. Ši taktika buvo neefektyvi.

Dar daugiau, lapkričio $15 \mathrm{~d}$. žinios apie britų ir sovietų derybas ir britų pasiūlymai Maskvai pateko ị spaudą. Frederickas Kuhas (United Press of America korespondentas Londone) tą dieną kreipesi i Fitzroy Macleaną prašydamas patvirtinti informaciją, kaip jis patikino, gautą iš sovietų šaltinio, kurị F. Macleanas manè esant Andrew Rothsteiną, TASS korespondentą Londone ${ }^{70}$. URM valstybès pavaduotojo Orme Sargento igaliotas, F. Macleanas patvirtino F. Kuho informaciją, kurios esmé buvo ta, kad „Sir Stafford Cripps had on the 22nd October proposed to M[onsieur] Vyshinsky an agreement under which Great Britain would promise the Soviet Union a part in any ultimate peace settlement, would undertake not to join any combination of hostile powers against the Soviet Union and would grant de facto recognition of the incorporation of the Baltic States in the Soviet Union..$^{7{ }^{1 / 2} 2}$ Bütina atkreipti dèmesĭ, kad informacija, patekusi ị spaudą, aprèpe išskirtinai Estiją, Latviją ir Lietuvą, bet nebuvo užsimenama apie Besarabiją, Šiaurès Bukoviną, Lenkiją ir juolab apie buvusią Lenkiją. Šią informaciją, jau žinomą United Press of America ir japonų agentūrai Domei, lapkričio 16 d. paskelbė News Chronicle, o lapkričio $18 \mathrm{~d}$. The Times. Jos viešas pateikimas negalëjo nesukelti didelio atgarsio.

Oficiali britų reakcija buvo S. Crippso išsiųstas A. Vyšinskiui raštas, kuriame kaip atsakinga už nutekinimą apkaltinta Sovietų šalis, tiksliau Sovietų ambasada Londone, ir išreikštas apgailestavimas sovietams neišlaikius britams svarbios paslapties ${ }^{73}$. Lapkričio 19 d. per pokalbị su S. Crippsu A. Vyšinskis išsakè protestą dèl kaltinimo sovietams sulaužius derybų paslaptị ir lapkričio $27 \mathrm{~d}$. laiške šią poziciją patvirtino, papildydamas iš Sovietų ambasados Londone gautomis žiniomis, pagal kurias būtent URM tarnautojai galèjo perduoti žurnalistams informaciją apie britų spalio $22 \mathrm{~d}$. pasiūlymus $^{74}$. Britų ambasadorius laikèsi ankstesnès nuomonès ${ }^{75}$, vis dèlto verta pastebèti, kad pats nebuvo

A. Vyšinskio pokalbio su S. Crippsu ataskaita, 2.11.1940, In: Документы внешней политики СССР. Том 23. Кн. 2 (часть 1). 1 ноября 1940 2. - 1 марта 1941 г.. Москва: Международные отношения, 1998, dok. 478, с. 13 ir c. 14.

67 Išsamiau šio vizito tema ir plačiau apie sovietų ir vokiečiu santykius šiuo laikotarpiu žr. Dębski, S. Między Berlinem a Moskwa: stosunki niemiecko-sowieckie 1939-1941, s. 418.

68 S. Crippso pranešimas URM, 10.11.1940, No. 976. TNA, FO 371/24852, N 7163/283/38.

69 S. Crippso pranešimai URM, 11.11.1940, No. 985 i 986. TNA, FO 371/24848, N.7165/40/38 ir N7166/40/38).

70 Didžiosios Britanijos žvalgybos duomenys rodè, kad daugeliu atvejų F. Kuho informatorius buvo pats ambasadorius Ivanas Majskis: John Maude (MI5), Williamui Codringtonui (FO), 28.10.1940; W. Codringtonas - J. Maude'ui, 1.11.1940. TNA, Records of the Security Service (KV), KV $2 / 985$.

71 „Seras Staffordas Crippsas spalio 22 d. pasiūle ponui Višinskiui sutartị, pagal kurią Didžioji Britanija pažadètų, kad Sovietų Sąjungai bus pasiūlyta dalyvauti bet kokiame galutiniame taikos susitarime, o ji nestos ị jokią Sovietų Sąjungai priešišką jègų koaliciją ir faktiškai užtikrins Baltijos valstybių inkorporavimo į Sovietų Sąjungą pripažinimą."

72 F. Macleano pažyma, 15.11.1940. TNA, FO 371/24848, N.7200/40/38. O. Sargento pažyma Halifaksui (paaiškinanti sutikimo patvirtinti informaciją priežastis), 15.11.1940. Ibidem. Halifaksas nebuvo patenkintas šia situacijos raida ir rašè: „Please ensure that no further 'official' communication should be made <...>“, 16.11.1940. Ibidem. Žr. taip pat pažymą apie pasiklausytą F. Kuho telefoninị pokalbị su F. Macleanu, 15.11.1940. TNA, KV 2/985.

S. Crippsas - A. Vyšinskiui, 16.11.1940. TNA, FO 371/29463.

A. Vyšinskis - S. Crippsui, 27.11.1940. Ibidem.

S. Crippsas - A. Vyšinskiui, 28.11.1940. Ibidem. 
įsitikinęs jos tikrumu. Kalbèdamasis su Amerikos ambasadoriumi Maskvoje Lawrencu Steinhardtenu jis tvirtino, jog informacijos nutekinimas buvo tam tikras URM sabotažas, kurị inspiravo „individuals in the British Government who were so hostile to the Soviet Union that they would prefer to risk the Empire rather than permit rapprochement to take place ${ }^{7677}$. Londonas del nutekinimo sutartinai kaltino sovietus, tačiau susidūrẻ su priekaištais, kai informacija tapo vieša. Ṣ̨̌ klausimą Karo kabinetas svarstė lapkričio $18 \mathrm{~d} .{ }^{78} \mathrm{~W}$. Churchillis išreiške nepasitenkinimą URM patvirtinus pranešimus apie $\mathrm{S}$. Crippso pasiūlymus, E. Halifaksas prisièmė atsakomybę už žinybos veiksmus ir tuo pat metu tikino, kad žala dèl paviešintos informacijos nèra itin didelè. Diskusijoje net atsirado argumentas, jog toks posūkis gali būti naudingas, nes kairieji britu visuomenès elementai gali ịsitikinti nepagrịstais JKD vyriausybès kaltinimais dèl trūkstamo noro gerinti santykius su SSRS. İdomu tai, kad net per Karo kabineto posèdị remtasi iliuzija, neva S. Crippso pasiūlymai aprépe tik Estiją, Latviją ir Lietuvą.

Tuo metu net ir tokie neišsamūs spaudos pranešimai sukèle rimto nerimo lenkų vyriausybei. Užsienio reikalų ministras Augustas Zaleskis šiuo klausimu jau buvo susitikęs su lordu E. Halifaksu lapkričio $18 \mathrm{~d}$. Jis protestavo dèl britų vyriausybès bandymo prisiimti įsipareigojimus dèl SSRS nesitariant su sąjungininke - lenkų vyriausybe. Jis pabrèžè, kad būtent Lenkija yra karo su Sovietų Sąjunga padèties ir bent jau dèl šios priežasties Lenkijos vyriausybè turètų būti informuojama apie SSRS leidimą dalyvauti būsimosiose taikos derybose. Tačiau pirmiausia jis siekè, kad būtų paaiškinta, ar Didžioji Britanija pasirengusi pripažinti Sovietų Sąjungos ịvykdytą Baltijos valstybių inkorporaciją de facto. Jis teiravosi, ar ši formuluote aprépia ir Lietuvą, ir teigè, kad pritarimo atveju turįs priminti, jog „there was no common frontier between Lithuania and the Soviet Union and that any recognition of the incorporation of Lithuania in the Soviet Union would therefore involve Polish territory also ${ }^{79 \text { c80 }^{\circ}}$. A. Zaleskis kritikavo ne tik britų pasiūlymų esmę, bet ir JKD vyriausybès pasirinktą veiksmų taktiką. Jis pabrèžè, kad sovietai britu pasiūlymus ịvertins kaip jų silpnybę, o ne gerą valią, ir matys jų turinyje papildomą mainų elementą deredamiesi su Vokietija. Be kita ko, A. Zaleskis kritikavo pasirinkimą S. Crippsui būti derybininku. Tvirtino, jog yra klaidinga manyti, kad kairiųjų pažiūrų politikai turètų daugiau šansų diskustuojant su sovietais. Atsakydamas i A. Zaleskio klausimus ir priekaištus E. Halifaksas patvirtino, jog britų vyriausybė kreipèsi su atitinkamais pasiūlymais ị Sovietų vyriausybę, kad palenktų ją atsisakyti provokiškos politikos. Jis taip pat pastebejo: „we had no illusions as to Soviet policy and we had been particularly careful as regards what we said about matters affecting Polish interests ${ }^{81 \text { c82 }^{2}}$. Šis argumentavimas dèl ypatingo atsargumo - palyginti su tuo, ką žinome apie S. Crippso pasiūlymų formuluotes ir apie britu vidaus diskusiją ta tema, - nereikalauja komentaro. E. Halifaksas žadejo A. Zaleskiui raštu pateikti britu vyriausybės poziciją aptartais klausimais. Lenkijos Ministrų tarybos nariai, informuoti A. Zaleskio apie pokalbio turinį, pranešimą prièmè su tam tikru palengvèjimu ir nusprendè susilaikyti nuo kokių nors atsakomụjų sprendimų, kol sulauks E. Halifakso laiško ${ }^{83}$. Svarbią poziciją užèmė premjeras W. Sikorskis. Jis pabrèžè: „Turime laikytis 1939 m. status quo, neliečiamybès pozicijos, kai kalbama apie Rytų sienas. “84 Tačiau ir jo kalba tryško optimizmu: pranešimuose apie britu ir sovietų santykius pastebejjo S. Crippso

${ }^{76}$ „Britų vyriausybès asmenys, buvę tiek priešiški Sovietų Sąjungai, jog būtų veikiau rizikavę imperija negu leidę atkurti draugiškus santykius“.

Cit. pagal: Hanak, H. Sir Stafford Cripps as British Ambassador in Moscow May 1940 to June 1941, p. 67.

Karo kabineto posedis, 18.11.1940, pkt. 5. TNA, CAB 65/10/0, WM (40) 290.

9 „Lietuva ir Sovietų Sąjunga neturi bendros sienos ir bet koks Lietuvos inkorporavimo ị Sovietų Sąjungą pripažinimas taip pat liestų ir Lenkijos teritoriją“.

80 E. Halifakso pokalbio su A. Zaleskiu ataskaita, 18.11.1940. TNA, FO 371/24482, C.12458/7177/55.

81 „dèl Sovietų politikos neturejome iliuzijų ir buvome ypač atsargūs kalbẻdami apie Lenkijos interesus liečiančius dalykus“.

Ibidem.

83 Informacijos ir propagandos ministerijoje svarstyta, pavyzdžiui, parengti laišką „The Times“ redakcijai, tačiau nuspręsta šio veiksmo atsisakyti.

84 Ministrų tarybos protokolas, 19.11.1940: Protokoły posiedzeń Rady Ministrów Rzeczypospolitej Polskiej. T. 2: czerwiec 1940 - czerwiec 1941 / redaktor naukowy Marian Zgórniak, opracował Wojciech Rojek przy współpracy Andrzeja Suchcitza. Kraków: Secesja, 1995, s. 181. 
nusivylimo būnant Maskvoje požymių, prarandant iliuzijas dèl tikrų Sovietų vyriausybės tikslų. Be kita ko, aptardamas susitikimą su E. Halifaksu Ministrų tarybos numatomo Lenkijos diplomatinių atstovybių pertvarkymo kontekste, ministras A. Zaleskis, be kita ko, pareiškè: „Visi mūsų bandymai suartèti su lietuviais, latviais ir estais šiuo pagrindu nepavyko. Latviai visiškai orientuoti ị Vokietiją, lietuviai iš esmès taip pat. Stokholme užmegztas ryšys su estais, nusiteikusiais proaliantiškai. Nepriklausomos orientacijos lietuviai neabejotinai yra Amerikoje, tačiau iki šiol su jais ryšys neužmegztas, tai bus viena iš naujojo Lenkijos Respublikos ambasadoriaus užduočių. " ${ }^{85}$ Taigi šios krypties veiksmai buvo nukeliami vèlesniam laikotarpiui, o kol kas viltys sietos su A. Zaleskio pokalbiu su E. Halifaksu.

Ne visi lenkai Londone siejo dideles viltis su laukiamu britų užsienio reikalų ministro raštu. Gerokai atsargesnį situacijos vertinimą rodo Lenkijos ambasados karinio ataše brigados generolo Bronisławo Regulskio pažyma. Jis rašè, kad raminantis E. Halifakso atsakymas A. Zaleskiui nepaneigia pavojaus, kuri S. Crippso nota kelia lenkų interesams. Jis teigè: „Ji liks visada precedentas, kuriuo galès remtis sovietai, aptardami mūsų rytų sienas $<\ldots>$ Mūsų rytų sienos bus aukojamos, jei ši auka bus reikalinga gauti sovietus kaip sąjungininkus. Britų veikejjams vis dar Cursono linija yra $<\ldots>$ Lenkijos bylos sprendimo Rusijos atžvilgiu raktas. ${ }^{\text {"I6 }}$ İdomu, kad B. Regulskis dar negalëjo žinoti, jog S. Crippso notoje buvo kalbama apie Lenkijos sienas. Tuo metu jis disponavo tik žiniomis apie planus pripažinti sovietų ǐvykdytą Baltijos valstybių aneksiją.

Šis konkretus klausimas tapo vienu iš svarbiausių diskusijos punktų URM rengiant pažadètą E. Halifakso raštą A. Zaleskiui. F. Macleanas, pateikdamas laiško projektą, rašè:

We can, I think, assume that M[onsieur] Zaleski does not realise that our proposals contained a specific reference to Soviet-occupied Poland, nor (fortunately) what were the terms of this reference. There is no need to emphasise in our reply that the proposals presented by Sir Stafford Cripps to M[onsieur] Vyshinsky explicitly mentioned Poland, but we can scarcely disguise the fact that our proposal covered Soviet-occupied Poland, and I have, therefore, thought it better to employ a comprehensive form of words covering all the Soviet Government's annexations. This makes it unnecessary to go into M[onsieur] Zaleski's rather silly reference to Lithuania $<\ldots>$ it was never suggested that we should recognise the incorporation of Lithuania in the Soviet Union separately from that of Latvia and Estonia, which would thus have provided a direct territorial connexion with the Soviet Union proper. Moreover, even if we had decided to recognise the incorporation of Lithuania alone, there would have been no reason why we should not have regarded it as a Soviet enclave on the lines of East Prussia before the war. In actual fact, however, it is our intention to grant de facto recognition of the Soviet occupation of Poland as well as of all three Baltic States so that the whole question is purely academic. $<\ldots>>{ }^{87,88}$

Šiuokart buvo pasirūpinta URM teisès patareją paklausti dèl rengiamo E. Halifakso rašto. Minètasis W. Malkinas pripažino, kad S. Crippso pavartotos pasiūlymų formuluotès, lenkų nuomone, buvo visai

Ibidem, s. 180

B. Regulskis - Leonui Mitkiewicziui, 21.11.1940. Polskie Dokumenty Dyplomatyczne 1940, redaktor tomu: Magdalena Hułas. Warszawa: Polski Instytut Spraw Międzynarodowych, 2010, dok. 478, s. 812-813. Pulk. Mitkiewiczius (Vyriausiojo vado II štabo skyriaus viršininkas) perdave pažymą Vyriausiojo vado štabo viršininkui brig. gen. Tadeuszui Klimeckiui. Ją taip pat gavo Vyriausiasis vadas gen. Sikorskis.

87 „Mano nuomone, panašu, kad p[onas] Zaleskis nesuvokia, jog mūsų pasiūlymuose ypač užsimenama apie Sovietų okupuotą Lenkiją ir (laimei), kokiais žodžiais apie tai užsimenama. Nèra reikalo mūsų atsakyme akcentuoti, kad sero Staffordo Crippso ponui Višinskiui pateiktuose pasiūlymuose tiesiogiai minima Lenkija, tačiau vargu, ar galime nuslèpti, kad mūsų pasiūlymas taikomas Sovietų okupuotai Lenkijai, todẻl maniau būsiant geriau vartoti žodžius, be užuolankų nusakančius visą Sovietų vyriausybès aneksijos spektrą. Todèl nèra prasmès kalbèti apie pono Zaleskio gana neprotingas užuominas apie Lietuvą $<\ldots>$ niekada nebuvo siūloma, kad turètume pripažinti Lietuvos inkorporavimą ị Sovietų Sajungą atskirai nuo Latvijos ir Estijos inkorporavimo ir taip kartu pripažinti tiesioginę teritorinę jungț̣ su Sovietų Sąjunga siaurąja prasme. Be to, jeigu būtume nusprendę pripažinti vien tik Lietuvos inkorporavimą, nebebūtų likę pagrindo nelaikyti jos Sovietų Sąjungos anklavu panašiai kaip Rytų Prūsija prieš karą. Tačiau iš tikrųjų mes norime pripažinti, kad Sovietų Sąunga yra de facto okupavusi Lenkiją ir visas tris Baltijos valstybes, todèl visas šis klausimas yra akademinio pobūdžio $<\ldots .$. ."

88 Note F. Macleana, 21.11.1940. TNA, FO 371/24482, C.12458/7177/55. 
netinkamos. Jis patarè, kad laiške A. Zaleskiui būtų pabrèžtas laikinas siūlytų sprendimų pobūdis, o būtinumą jas priimti pagrịsti tuo, kad rusai: „are in fact in control of those territories, and that without recognising this fact it is impossible for us to deal with matters affecting British interests in those territories, which can only be dealt with on the basis of the de facto situation. ${ }^{89490}$

Galiausiai E. Halifaksas parengė laišką A. Zaleskiui lapkričio $27 \mathrm{~d} \cdot{ }^{91}$ Jis pripažino, kad pasiūlymai, skirti Sovietų vyriausybei, aprépe pasiūlymą laikinai, t. y. iki bus priimti galutiniai sprendimai karo pabaigoje, pripažinti SSRS nuo pat karo pradžios užimtų teritorijų „kontrolę de facto“. Dar E. Halifaksas rèmèsi W. Churchillio pareiškimu Bendruomenių rūmuose ir $1940 \mathrm{~m}$. rugsèjo $5 \mathrm{~d}$. Lordų rūmuose pasakyta savo kalba ${ }^{92}$ dèl JKD vyriausybès pozicijos nepripažinti teritorinių pakeitimų, atliktų per karą, ir patikino, jog pasiūlymai, pateikti Sovietų vyriausybei, šios nuostatos niekaip nesilpnina. Dar daugiau, painiai stengèsi ittikinti, kad šios nuostatos nekvestionuoja:

As it would clearly be impossible to exclude the Soviet Government from such a settlement [of the future of the territories concerned], our offer to consult them about it may be regarded as a necessary consequence of our refusal to recognize enforced territorial changes which take place during the war. ${ }^{93,94}$

Kiek kitaip E. Halifaksas vetino galimybes pasipriešinti imperinei SSRS politikai laiške, tą pačią dieną išsiųstame S. Crippsui. Jis vertino sovietų politikus kaip realistus, kurie tikisi abipusio Vokietijos ir Didžiosios Britanijos išsekimo, ir tai sukurtų aplinkybes, kuriomis Sovietų Sąunga bus pajègi „to impose its will on a Europe ripe for revolution ${ }^{95{ }^{496}}$. A. Zaleskis E. Halifakso laišką gruodžio 2 d. pristatė Ministrų tarybos posèdyje; jis tvirtino, kad laiško turinys rodo pažangą, palyginti su ankstesnèmis britų deklaracijomis, tačiau nurodè, jog reikia tęsti susirašinėjimą, „kad pasiektume visišką mūsų požiūrio dèl Rytų sienų pripažinimą ${ }^{\text {“97} . ~ K l i u ̄ t i s, ~ j o ~ m a n y m u, ~ b u v o ~ L e n k i j o s ~ i r ~ D i d z ̌ i o s i o s ~ B r i t a n i j o s ~} 1939$ m. rugpjūčio 29 d. sutarties slaptasis protokolas, „parodantis skirtumus tarp Lenkijos rytinių ir vakarinių sienų“. O A. Zaleskio nuomone, paramos galëjo suteikti Franklinas D. Rooseveltas. Užsienio reikalų ministras kaip pavyzdį pateikè ši faktą: Amerikos Prezidentui prièmus „Amerikos lietuvių delegaciją, kuriai <...> pareiške labai ryžtingai, jog Lietuva po karo bus nepriklausoma ir kad jis tai garantuoja“. Ministrų tarybos nariai teigiamai, nors ir santūriai vertino E. Halifakso laišką. Diskusiją apibendrino premjeras W. Sikorskis, pabrēždamas, kad Ministrų taryba „<...> paveda ministrui Zaleskiui tęsti derybas su britų užsienio reikalų ministru siekiant mūsų pozicijos sovietų klausimu pripažinimo“, ir kad „Roosevelto pareiškimas dèl Amerikos lietuvių turi būti mūsų propagandos atitinkamai išnaudotas“.

A. Zaleskis atsakè E. Halifaksui gruodžio 14 d. ${ }^{98}$ Išsamiame rašte jis pateikè lenkų vyriausybės požiūrị ¡ Lenkijos Respublikos rytinių teritorijų okupaciją ir komentarą dèl britų ministro formuluotès „de facto control“ Sovietų Sąungos, okupavusios teritorijas, atžvilgiu. Jis atkreipe dèmesị i faktą, kad $1907 \mathrm{~m}$. Hagos konvencija gana aiškiai apibrěžia okupacinių valdžių teises ir pareigas, tad jeigu britų pasiūlymas pri-

89 „de facto kontroliuoja šias teritorijas ir kad nepripažįstant šio fakto neįmanoma spręsti su Britanijos interesais šiose teritorijose susijusius klausimus, kurie gali būti sprendžiami tik remiantis faktine situacija“.

$90 \quad$ Note W. Malkina, 22.11.1940. Ibidem.

91 Documents on Polish-Soviet Relations, 1939-1945. Vol. 1: (1939-1943), Eds. General Sikorski Historical Institute. London: Heinemann 1961, dok. 80, p. 97.

92 Poland in the British Parliament. 1939-1945. Vol. I: British Guarantees to Poland to The Atlantic Charter (March 1939-August 1941), p. 444-445.

93 „Neabejotinai būtų neįmanoma pašalinti Sovietų vyriausybę iš tokio susitarimo [dèl atitinkamų teritorijų ateities], todèl mūsų pasiūlymą su jais tartis galima laikyti būtina mūsų atsisakymo pripažinti per karą primestas teritorines permainas pasekme."

Documents on Polish-Soviet Relations, 1939-1945. Vol. 1: (1939-1943), s. 98.

"Primesti perversmui subrendusiai Europai savo valią."

E. Halifaksas - S. Crippsui, 27.11.1940. BL, SC-5.

Ministrų tarybos posėdžio protokolas, 2.12.1940, In: Protokoły posiedzeń Rady Ministrów Rzeczypospolitej Polskiej. T. 2: czerwiec 1940 - czerwiec 1941, s. 198

98 A. Zaleskis - E. Halifaksui, 14.12.1940, In: Documents on Polish-Soviet Relations, 1939-1945. Vol. 1: (1939-1943), dok. 81, p. 98-101. Ministrų tarybos nariai A. Zaleskio laišką laike labai gerai suredaguotu, tačiau Ministras Pirmininkas W. Sikorskis ministrui nurodè, kad ateityje tokios svarbos klausimais jis prieš išsiųsdamas laiškų turinị aptartų su vyriausybe; žr. Ministrų tarybos posèdžio protokolas, 19.12.1940, In: Protokoły posiedzeń Rady Ministrów Rzeczypospolitej Polskiej. T. 2: czerwiec 1940 - czerwiec 1941, s. 212. 
pažinti reiškia vien Hagos nuostatų patvirtinimą, ji galima vertinti kaip nereikalingą (superflous); tačiau jeigu šios nuostatos peržengtos, tai neabejotinai yra pavojingas precedentas. Su pasitenkinimu apibūdino E. Halifakso nuorodą $\mathfrak{i}$ W. Churchillio ir jo paties rugsèjo 5 d. pareiškimus. Britų ísipareigojimų konsultuotis su SSRS dèl pokarinès tvarkos klausimu A. Zaleskis apibūdino kaip „necessity of Soviet participation in the discussion of the liquidation of the Russian temporary occupation of the territories concerned, after the war ${ }^{996}$, ir pabrèžè, jog ir šiuos sprendimus priimti būtų per ankstyva. Vis dèlto jis patikino pripažįstantis naudą, kurios galètų gauti Lenkija iš Didžiosios Britanijos konsultacijų su Sovietų Sąjunga, nes neabejoja, jog lenkų šalis gali tikètis britų paramos teritorijų ir suverenumo klausimais. Toliau jis pristatė Lenkijos vyriausybės požiūrị $\mathfrak{i}$ Lenkijos Respublikos rytinių teritorijų okupaciją, siūlydamas atsižvelgti $\mathfrak{i}$ lenkų ir rusų (sovietų) santykių istoriją, priminè dvišalių tarptautinių sutarčių nuostatas, kurias pamynè sovietų agresija ir aneksija.

Vienas iš faktų, ị kurị jis atkreipé dèmesị, buvo Sovietų Sąjungos dalies užimtos Lenkijos teritorijos (Vilnijos) $1939 \mathrm{~m}$. spalio $10 \mathrm{~d}$. perdavimas Lietuvai, o vèliau iš naujo šios teritorijos perèmimas su visa Lietuva 1940 m. rugpjūčio 3 d. Jis pabrèžè, kad galimas tarptautinis Lietuvos teritorijos aneksavimo pripažinimas sukurtų rimtą problemą ne tik todèl, jog tai lygiagrečiai reikštų Vilnijos aneksijos pripažinimą - ṣ̨̌ kraštą esant Lenkijos Respublikos dalimi. Esminga yra tai, jog slaptame Lenkijos ir Didžiosios Britanijos sutarties protokole (2b str.) pripažinta, kad Lietuva gyvybiniams Lenkijos interesams turi tokios reikšmès kaip Belgija ir Olandija - Didžiosios Britanijos interesams. A. Zaleskis taip pat rémèsi savo pokalbiais ir susirašinèjimu su E. Halifaksu po jo 1939 m. spalio 26 d. pareiškimo, kuriame buvo apibrèžta abiejų šalių pozicija dèl Sovietų Sąjungos. Jis taip pat palaikè pasirengimą toliau keistis nuomonėmis šia tema. Tai visiškai netiko britams. URM nuomonès apie A. Zaleskio laišką buvo skirtingos, bet jas vienijo nuostata, kad reikia baigti keistis pastabomis šiuo klausimu.

Jamesas Youngas Mackenzie perspèjo, kad lenkai pasirengę susirašinèti ad infinitum, Frankas Kenyonas Robertsas teigè, kad susirašinèjimą tęsti yra netikslinga, ir rekomendavo glaustai, be ịsipareigojimų patvirtinti laiško gavimą. Kai šiems pasiūlymams pritare L. Collier ir nuolatinis URM valstybès pavaduotojas Aleksandras Cadoganas ${ }^{100}$, pasikeite užsienio reikalų ministras. Mirus JKD ambasadoriui Vašingtone lordui Lothianui, i jo vietą buvo paskirtas lordas E. Halifaksas, o ministro krèslą URM užèmė Anthony Edenas. Būtent jis baigè S. Crippso memorandumo klausimą santykiuose su lenkais. Gruodžio $28 \mathrm{~d}$. jis susitiko su Lenkijos užsienio reikalų ministru; A. Zaleskis, remdamasis savo susirašinèjimu su E. Halifaksu, pakartotinai išreiške susirūpinimą dèl britų bandymų susitarti su SSRS, kuriais ignoruoti Lenkijos interesai. A. Edenas įtikinėjo pašnekovą ramindamas, kad dieną per susitikimą su Ivanu Ma-

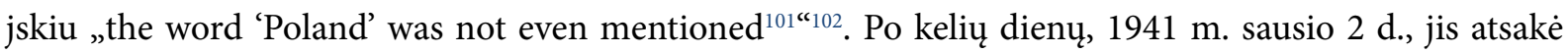
A. Zaleskiui ị E. Halifakso gruodžio 14 d. laišką dviem sakiniais, tvirtindamas, kad susipažino su lenkų pozicija, ir pakartotinai priminè $1940 \mathrm{~m}$. rugsèjo $5 \mathrm{~d}$. britų pareiškimus ${ }^{103}$. Sausio $6 \mathrm{~d}$. A. Zaleskis atsakè vienu sakiniu, išreikšdamas pasitenkinimą dèl to, kad britai teigè, jog Lenkijos vyriausybès pozicija, išdèstyta gruodžio $14 \mathrm{~d}$. laiške, yra garantuota britų rugsèjo $5 \mathrm{~d}$. pareiškimais. Taip buvo baigtas lenkų ir britų susirašinejimas, tiesiogiai susijęs su spalio $22 \mathrm{~d}$. memorandumu.

Per minètą A. Edeno pokalbị su I. Majskiu gruodžio 27 d. žodis „Lenkija“ iš tikrujų neištartas. Tuo metu pirmiausia aptarti Baltijos valstybių reikalai. I. Majskis susiejo sovietų ir britų santykių pagerinimo galimybę su A. Edeno veiksmais šiuo klausimu. Jis teigè, kad britų užsienio reikalų ministras „должен

„būtinybę siekiant, kad Sovietų Sąjunga dalyvautų svarstymuose dèl Rusijos vykdomos laikinos atitinkamų teritorijų okupacijos likvidavimo karui pasibaigus".

100 Žr. J. Y. Mackenzie pažyma, 20.12.1940; F. K. Robertso pažyma, 21.12.1940; L. Collier pastaba, 23.12.1940; A. Cadogano pastaba, 29.12.1940. TNA, FO 371/24482, C.13465/7177/55.

101 „Žodis „Lenkija“ nė nebuvo ištartas“.

102 A. Edeno pokalbio su A.Zaleskiu ataskaita, 28.12.1940. TNA, Foreign Office: Confidential Print (FO 417), FO417/41, C.13951/7177/55.

103 A. Edenas A. Zaleskiui - 2.01.1941. TNA, FO 371/24482, C.13465/7177/55. 
заняться расчисткой почвы (to clear away debris) в балтийском вопросе ${ }^{104{ }^{10} 105}$. Vis delto A. Edenas vengė kokio nors pareiškimo, aiškindamas tik neseniai gavęs užsienio reikalų ministro portfelị ir esą ne su visais reikalais suspejjęs susipažinti. Tikroji problema buvo kur kas gilesnè: ji aprèpè ne tik A. Edeno informuotumo lygi, bet ir britų politikos SSRS ir Vidurio ir Rytų Europos atžvilgiu esmę.

Taigi per pokalbị su I. Majskiu A. Edenas neprisiminė Lenkijos, Baltijos šalių klausimu nuomonès nereiškè. Tačiau du kartus pasirèmé pareiškimu apie savo 1935 m. vizitą Maskvoje, kuriame buvo teigiama, kad tarp JKD ir SSRS vyriausybių nèra jokio interesų konflikto kokiu nors užsienio politikos klausimu. Šie žodžiai, ištarti tuo metu, kai Sovietų Sąunga vykdè pusės Lenkijos teritorijos, visos Estijos, Latvijos ir Lietuvos bei dalies Rumunijos „de facto control“, nieko gero šioms šalims negalejo lemti.

Is lenku kalbos vertè Andrius Vaišnys

\section{Archyviniai šaltiniai}

Bodleian Library, Oxford - BL

- Sir Stafford Cripps' Papers (depozyt Nuffield College) - SC

The National Archives, Kew - TNA

- Foreign Office: General Correspondence - FO 371

- Foreign Office: Confidential Print - FO 417

- Prime Minister's Office: Operational Papers - PREM 3

- Records of the Security Service - KV

- War Cabinet: Minutes and Conclusions of the War Cabinet, WM Series - CAB 65

\section{Publikuoti šaltiniai ir literatūra}

Berska, Barbara. Kłopotliwy sojusznik. Wplyw dyplomacji brytyjskiej na stosunki polsko-sowieckie w latach 1939-1943. Kraków: Księgarnia Akademicka, 2005.

Burgess, Simon. Stafford Cripps: A Political Life. London: Gollancz, 1999.

Documents on Polish-Soviet Relations, 1939-1945. Vol. 1: (1939-1943), Eds. General Sikorski Historical Institute. London: Heinemann 1961.

Cienciala, Anna M. The Question of the Polish-Soviet Frontier in 1939-1940: The Litauer Memorandum and Sikorski's Proposal for Re-establishing Polish-Soviet Relations. The Polish Review, 1988, Vol. 33, No. 3, p. 295-323. Taip pat prieiga per internetą: https://www.jstor.org/stable/25778368

Clarke, Peter. The Cripps Version: The Life of Sir Stafford Cripps, 1889-1952. London: Allen Lane, The Penguin Press, 2002.

Cooke, Colin Arthur. The Life of Richard Stafford Cripps. London: Hodder and Stoughton, 1957.

Dębski, Sławomir. Między Berlinem a Moskwą: stosunki niemiecko-sowieckie 1939-1941. Warszawa: Polski Instytut Spraw Międzynarodowych, 2003.

Estorick, Eric. Stafford Cripps: Master Statesman. New York: The John Day Company, 1949.

„turi pašalinti neaiškumus, susijusius su Baltijos valstybių klausimu“.

105 I. Majskio pokalbio su A. Edenu ataskaita, 27.12.1940. In: Документы внешней политики СССР. Том 23. Кн. 2 (часть 1). 1 ноября 1940 г. - 1 марта 1941 г., dok. 614, с. 239. Ataskaita anglų k. žr. TNA, FO 371/24849, N.7548/40/38. 
Gorodetsky, Gabriel. Stafford Cripps' Mission to Moscow, 1940-1942. Cambridge: Cambridge University Press, 1984.

Gorodetsky, Gabriel (Ed.). Stafford Cripps in Moscow, 1940-1942: Diaries and Papers. London and Portland, OR: Vallentine Mitchell, 2007.

Hanak, H[arry]. Sir Stafford Cripps as British Ambassador in Moscow May 1940 to June 1941. The English Historical Review, 1979, Vol. 94, No. 370, p. 48-70. Taip pat prieiga per internetą: http://www.jstor.org/stable/567157

Hanak, H[arry]. Sir Stafford Cripps as Ambassador in Moscow, June 1941-January 1942. The English Historical Review, 1982, Vol. 97, No. 383, p. 332-344. Taip pat prieiga per internetą: https://www.jstor.org/stable/568120

Hułas, Magdalena. Memorandum Stafforda Crippsa z 22 października 1940 r. Polskie aspekty. Dzieje Najnowsze, 1993 , t. 25, z. 4, s. 81-93.

Merritt, Merritt S. Between Churchill and Stalin: The Soviet Union, Great Britain, and the Origins of the Grand Alliance. Chapel Hill: University of North Carolina Press, 1988.

Osborn, Patrick R. Operation Pike: Britain versus the Soviet Union, 1939-1941. Westport, CT and London: Greenwood Press, 2000.

Osborn, P. R. Brytyjskie plany ataku na ZSRR 1939-1941. Warszawa: Wydawnictwo Amber, 2007.

Piirimäe, Kaarel. Roosevelt, Churchill, and the Baltic Question: Allied Relations during the Second World War. New York: Palgrave Macmillan, 2014.

Poland in the British Parliament. 1939-1945. Vol. I: British Guarantees to Poland to The Atlantic Charter (March 1939August 1941). Compiled and edited by Wacław Jędrzejewicz with the assistance of Pauline C. Ramsey. New York: Jozef Pilsudski Institute of America for Research in the Modern History of Poland, 1946.

Polskie Dokumenty Dyplomatyczne 1940, redaktor tomu: Magdalena Hułas. Warszawa: Polski Instytut Spraw Międzynarodowych, 2010.

Protokoły posiedzeń Rady Ministrów Rzeczypospolitej Polskiej. T. 2: czerwiec 1940 - czerwiec 1941 / redaktor naukowy Marian Zgórniak, opracował Wojciech Rojek przy współpracy Andrzeja Suchcitza. Kraków: Secesja, 1995.

Tamkin, Nicholas. Britain, Turkey and the Soviet Union, 1940-45: Strategy, Diplomacy and Intelligence in the Eastern Mediterranean. New York: Palgrave Macmillan, 2009.

Tebinka, Jacek. Polityka brytyjska wobec problemu granicy polsko-radzieckiej 1939-1945. Warszawa: Wydawn, Neriton, 1998.

The Foreign Office and the Kremlin: British documents on Anglo-Soviet Relations, 1941-45, Edited, with an introduction, by Graham Ross. Cambridge: Cambridge University Press, 1984.

Wandycz, Piotr. Z Piłsudskim i Sikorskim. August Zaleski, minister spraw zagranicznych w latach 1926-1932 $i$ 1939-1941. Warszawa: Wydawn. Sejmowe, 1999.

Woodward, Llewellyn. British Foreign Policy in the Second World War, Vol. I. London: H. M. Stationery Office, 1970.

Документы внешней политики СССР. Том 23. Кн. 1.1 января - 31 октября 1940 г. Москва: Международные отношения, 1995.

Документы внешней политики СССР. Том 23. Кн. 2 (часть 1). 1 ноября 1940 г. - 1 марта 1941 г. Москва: Международные отношения, 1998.

Лавров, Владимир Сергеевич. Что скрывалось за приглашением В. М. Молотова осенью 1940 г. в Берлин и полетом Р. Гесса в мае 1941 г. в Англию. In: Международный кризис 1939-1941 г2.: от советско-германских договоров 1939 г. до нападения Германии на СССР. Москва: Права человека, 2006, с. 357-385.

Майский, Иван Михайлович. Дневник дипломата, Лондон, 1934-1943: книга 2, часть 1: 4 сентября 1939 21 июня 1941 года / отв. ред. А. О. Чубарьян; сост. Н. В. Бойко, Е. В. Косырева, Л. В. Поздеева. Москва: Наука, 2009. 